\title{
Nomenclatural notes on Rubus lasiostylus (Rosaceae) and lectotypification of three names in Rubus
}

\author{
S.S. Dash ${ }^{1 *}$, C. Gupta ${ }^{2}$
}

Key words

India

lectotypification

new record

nomenclature

Rubus lasiostylus
Abstract A revised classification of infraspecific taxa of Rubus lasiostylus (Rosaceae) is presented and three lectotypifications, i.e., Rubus lasiostylus, Rubus lasiostylus var. glabratus and Rubus eucalyptus are proposed. Rubus lasiostylus var. lasiostylus is reported for the first time from Arunachal Pradesh, India. It was previously known only from China. A detailed description and a field photograph of $R$. lasiostylus var. lasiostylus is provided for easy identification.

Published on 29 August 2017

\section{INTRODUCTION}

The genus Rubus L. (1753: 492) is distributed worldwide. Members of the genus exhibit great morphological variation in habit, foliar and floral structure (Naruhashi 1980, Kalkman 1993). In the last revision of Rubus in an Indian context (Hooker 1878), 39 species and 15 varieties were recorded from present-day India. Since Hooker's time, few species have been added to the genus from India (Kanjilal et al. 1922, Sharma \& Kachroo 1981, Chowdhery \& Wadhwa 1984, Long 1987, Chowdhery et al. 1996). Current estimates show more than 75 species of Rubus in India, distributed mainly in dense primary or secondary forests from tropical to temperate regions at altitudes ranging from 300 to 3500 m (Gupta \& Dash 2015). The greatest diversity is in the eastern Himalayan states of Arunachal Pradesh and Sikkim.

During identification of some recent collections, we came across an interesting specimen of Rubus collected from the subtropical forests of the Dibang Valley district of Arunachal Pradesh, India. Based on the literature (Smith 1819, Roxburgh 1832, Hooker 1878, Kuntze 1879, Focke 1910, 1911, 1914, Kalkman 1993, Lu \& Boufford 2003, Boufford et al. 2011) and a comparison of specimens from many herbaria $\left(A^{*}, B M^{*}, B S D\right.$, BSHC, BSI, CAL, DD, GH* $\mathrm{K}^{*}, \mathrm{~L}^{*}$, LWG, MH, NY*, $\mathrm{P}^{*}, \mathrm{PBL}$, $\mathrm{PE}^{*}, \mathrm{US}^{*}:-{ }^{*}$ denotes digital images seen only), the plant was determined to be Rubus lasiostylus Focke (1891) of subgenus Idaeobatus (Focke 1874), hitherto not reported from India. We document this new range extension here, with a taxonomic and nomenclatural note about the infraspecific taxa along with an illustration (Fig.1) and a photograph of the living plant taken in the field (Fig. 2a).

\section{MATERIAL AND METHODS}

This study is based on an examination of the relevant literature and of specimens kept in several herbaria (acronyms according to Thiers 2016). The morphological description of the species

\footnotetext{
${ }^{1}$ Botanical Survey of India, CGO Complex, Salt Lake City, Kolkata - 700 064, West Bengal, India; corresponding author e-mail: ssdash2002@gmail.com.

2 Central National Herbarium, Botanical Survey of India, Howrah - 711 103, West Bengal, India.
}

newly recorded for India is based on the Indian specimen, M.K. Pathak 4099, in the Central National Herbarium (CAL) and on field surveys. For the selection of lectotype, the protologues have been compared with original material and the most complete and informative specimens were selected (Art. 9.3 of the ICN, McNeill et al. 2012).

\section{Nomenclatural notes}

Focke (1891) recognised three formae under Rubus lasiostylus, the typical one and forma glabratus ('glabrata') and forma glandulosus ('glandulosa'). While dealing with the typical one he cited a single type collection (A. Henry 5788A) for forma typica et tomentosa ('forma typica et tomentosa: ramis petiolis pedunculis sepalisque dense tomentosis, District Patung Henry 5788 A'). The word typica, importantly not in italics, clearly indicates that he is treating the typical form under the name 'tomentosa'. Later, Focke (1911) treated forma glandulosus as a new species, $R$. eucalyptus. In this case the epithet 'glandulosa' could not be used due to precedence of $R$. glandulosus Bellardi (1793).

Based on indument and fruit characters, Lu \& Boufford (2003) recognised five infraspecific taxa within Rubus lasiostylus, viz., var. lasiostylus; var. dizygos Focke, var. eglandulosus Focke, var. hubeiensis and var. tomentosus Focke. As Lu \& Boufford do not state 'stat. nov.' for their varieties, it is open to question whether they are properly made in such a recent publication (Art.32 of ICN, McNeill et al. 2012). We could not trace the name Rubus lasiostylus var. eglandulosus Focke from the reference provided by Lu \& Boufford. So we concluded that their usage of 'Rubus lasiostylus var. eglandulosus Focke, Hooker's Icon. PI., ser. 3, 10: t. 1951. 1891', is a typographical error for $R u$ bus lasiostylus forma glandulosus Focke. Moreover, this plant is marked by its glandular nature which agrees with Rubus lasiostylus forma glandulosus Focke (1891). Therefore we exclude the name 'eglandulosus' from the infraspecific taxa of $R$. lasiostylus. We note with satisfaction that recently both names var. eglandulosus and var. tomentosus have been deleted from the online version of the Flora of China (efloras.org). Furthermore, Lu \& Boufford (2003) included R. lasiostylus forma glabrata Focke under $R$. lasiostylus var. lasiostylus. But examination of the original type images/material A.Henry $5788 A$ revealed that the branches, petioles, peduncles, pedicels 
and calyx are densely tomentose, while the original/authentic type images/material A. Henry 5788 \& 5788C (types of Rubus lasiostylus forma glabrata by Focke) is glabrous. These characters are also in agreement with the protologue. Hence we exclude forma glabrata from the typical variety and propose the name Rubus lasiostylus var. glabratus (Focke) Chand. Gupta \& S.S.Dash for this plant and lectotypify it to ensure unambiguous use.

Based on our study, the following infraspecific rearrangement within Rubus lasiostylus is proposed.

\section{KEY TO THE VARIETIES OF RUBUS LASIOSTYLUS}

1. Branches, petioles, pedicels and abaxial surface of calyx densely tomentose. . . . . . . . . . . . var. lasiostylus

1. Branches, petioles, pedicels and abaxial surface of calyx glabrous or pubescent . . . . . . . . . . . . 2
2. Pedicels and abaxial surface of calyx glabrous ........ $\ldots \ldots \ldots \ldots \ldots \ldots$. . . . . . . . . . . . . . . . . . .

2. Pedicels and abaxial surface of calyx pubescent .... 3

3. Leaves 3(-5)-foliolate, stipules and bracts ovate to suborbicular . . . .................. var. hubeiensis

3. Leaves 5(-7)-foliolate, stipules and bracts ovate-lanceolate. . . . . . . . . . . . . . . . . . var. dizygos

\section{TYPIFICATION OF THE NAMES}

Rubus lasiostylus Focke (1891) t. 1951

Rubus lasiostylus Focke var. lasiostylus.

Rubus lasiostylus forma tomentosus Focke (1891) t. 1951 (as forma 'tomentosa'), nom. inval.; R. lasiostylus var. tomentosus Focke in Lu \& Boufford (2003) 232, nom. inval.

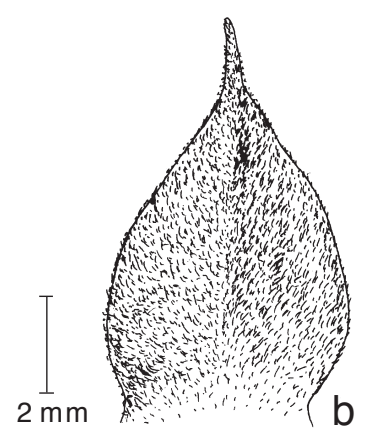

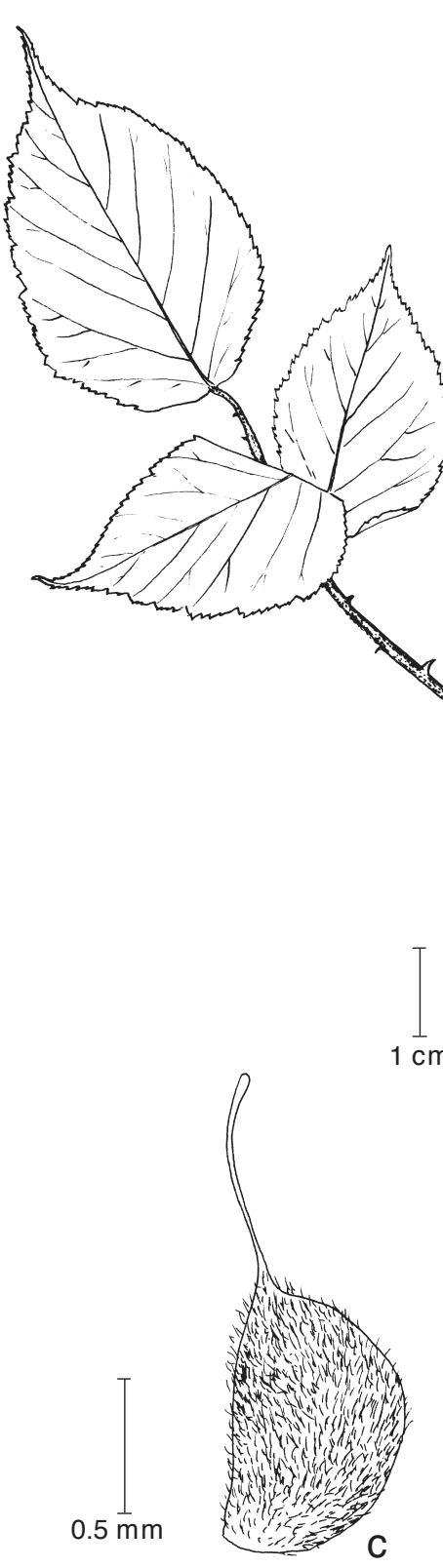

Fig. 1 Rubus lasiostylus Focke var. lasiostylus a. Flowering twig; b. lobe of calyx; c. pistil (M.K. Pathak 4099, CAL). 
Type. Augustine Henry 5788A (lectotype designated here $\mathrm{K}^{*}$, http:// specimens.kew.org/herbarium/K000737817; isolectotypes $\mathrm{BM}^{*}, \mathrm{CAL}, \mathrm{GH}^{\star}$ ), China, Hupeh [Hubei], Patung [Badong], Mar. 1889. - Fig. 2b.

Diagnostic characters - Branches, petioles, pedicels and abaxial surface of calyx densely tomentose. Leaves 3-5-foliolate. Stipules and bracts linear-lanceolate. Bracts up to $8 \mathrm{~mm}$ long. Densely yellow tomentose or woolly drupelets. Styles pubescent that tend to be persistent. Red colour of drupelets (whitish, tannish when dry).

Distribution - India (Arunachal Pradesh), China. Rubus lasiostylus has been assumed to be endemic to China (Hubei Province). However, the collection from Dibang Valley, Arunachal Pradesh, confirms its presence in India and also constitutes a new addition to Rubus in India.
Specimen examined. INDIA, Arunachal Pradesh, Dibang Valley, Pasopani - Tahupani, 30 June 2002, M.K. Pathak 4099 (CAL).

Notes - Focke (1891) described $R$. lasiostylus on the basis of specimens collected on March 1889 by Augustine Henry from Patung [Badong], Hupeh [Hubei] Province, central China. We found specimens in $\mathrm{GH}^{*}, \mathrm{~K}^{*}$ and $\mathrm{BM}^{*}$ that can be considered original material. The single herbarium sheet in $\mathrm{BM}^{*}$ (barcodes BM000622276, BM000622277) has specimens with two different field numbers (upper 5788; lower 5788A). The specimen at $\mathrm{K}^{*}$ (barcode $\mathrm{K} 000737817$ ) has an original annotation 'typica et tomentosa' by Focke himself and is selected here as the lectotype (Fig. 2a). The other four specimens, no. 0000011654 and 0000011657 (CAL); no. $0040643\left(\mathrm{GH}^{*}\right.$, all three twigs) and no. BM000622277 $\left(\mathrm{BM}^{\star}\right)$ are considered as isolectotypes.
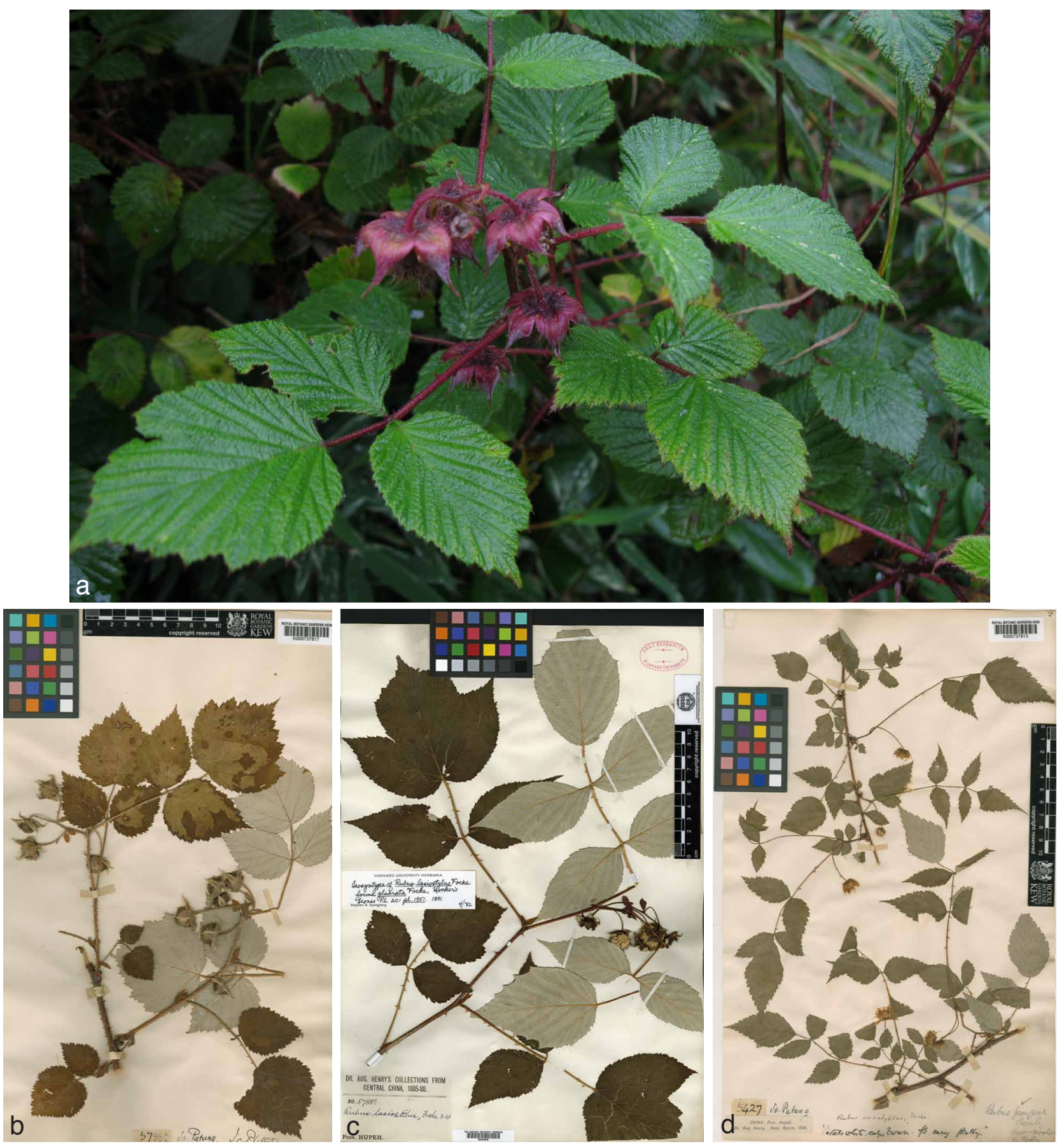

Fig. 2 a. Field photograph of Rubus lasiostylus Focke var. lasiostylus; b. lectotype image of Rubus lasiostylus Focke var. lasiostylus (K); c. lectotype image of Rubus lasiostylus Focke forma glabratus Focke $(\mathrm{GH})$; d. lectotype image of Rubus eucalyptus Focke (K). 


\section{Rubus lasiostylus var. glabratus (Focke) Chand.Gupta \& S.S.Dash, stat. nov.}

Basionym. Rubus lasiostylus forma glabratus Focke in Hooker's Icon.: pl. 20 (ser. 3, 10) (1891) t. 1951 (as 'forma glabrata').

Type. Augustine Henry 5788C (lectotype designated here: GH barcode 00040646*, https://s3.amazonaws.com/huhwebimages/A868B955383D4A3/ type/full/40646.jpg; accessed on 22 Apr. 2017; isolectotypes CAL), China, Hupeh [Hubei]. — Fig. 2c.

Diagnostic characters - Branches, petioles, pedicels and abaxial surface of calyx glabrous. Leaves 3-5-foliolate. Stipules and bracts ovate-lanceolate. Bracts up to $15 \mathrm{~mm}$ long.

Distribution - Known only from China (Hubei, Shaanxi, Sichuan, Yunnan provinces).

Additional specimens studied. CHINA, Hupeh [Hubei], Mar. 1889, Augustine Henry 5788 (A barcodes 00277289*, 00040647*, BM barcode 000622276*, CAL barcodes 0000011656, 0000011659, 0000011660, US barcode $\left.00097934^{*}\right)$.

Note - We could trace four specimens in A, BM, CAL, GH and US which can be considered to be original material. On examination, we found that Henry 5788C (GH barcode 00040646, both twigs) has all the distinct characters as specified in the protologue and thus we selected it as the lectotype and the specimens at CAL (barcodes 0000011653, 0000011655) as isolectotypes.

\section{Rubus eucalyptus Focke (1911) 169}

Rubus lasiostylus forma glandulosus Focke (1891) t. 1951 (as 'forma glandulosa').

Type. Henry 5427 (lectotype designated here, K barcode 000737813*, http://specimens.kew.org/herbarium/K000737813; isolectotypes BM, barcode 000885494*, P barcode 00755212*), Central China, Hupeh, So Patung, March 1889. - Fig. 2d.

Diagnostic characters - Stem, branches, petioles and pedicels glandular. Leaves rhombic-ovate, thin grey-tomentose abaxially. Flowers white.

Distribution - This species is only reported from China (Gansu, Guizhou, Hubei, Shaanxi, Sichuan).

Additional specimens studied. CHINA, Central China, Hupeh, Cheinshih, Henry 5872 (CAL 0000011658, GH barcode 00040580*, NY barcode 00429691*, US 00097935*); Western China, Chienshi, E.H. Wilson 950 (A barcode $00040584^{\star}$, NY barcode $429677^{\star}$ ).

Notes - Focke (1911) while describing this species included the type specimen of Rubus lasiostylus forma glandulosus. Later, Lu \& Boufford (2003) also synonymized forma glandulosus under $R$. eucalyptus as the characters are overlapping. We found three specimens of $R$. eucalyptus (A. Henry 5427) each from $\mathrm{K}^{*}$ (barcode 000737813), BM* (barcode 000885494) and $\mathrm{P}^{*}$ (barcode 00755212). The specimen at $\mathrm{K}^{*}$ is best fitted to the protologue and it also bears author's annotations and hence selected here as lectotype (Fig. 2d) and the rest of the specimens as isolectotypes.

Acknowledgements We are grateful to Dr. Paramjit Singh, Director, Botanical Survey of India, for encouragement and providing the necessary facilities; Dr. K.N. Gandhi, Senior Nomenclatural Registrar, for nomenclature input. Our thanks are due to Dr. Gopal Krishna, Sr. Preservative Asst., Central National Herbarium, Botanical Survey of India, for providing the field photograph and to the curators and directors of A, BM, GH, NY, US for providing access to the digital images of the type/original specimens. Professor David J. Mabberley (L, NSW) helped improve the manuscript.

\section{REFERENCES}

Bellardi, CAL. 1793. Appendix Ludovici Bellardi ad Floram Pedemontanam. Memoires de l'Academie Royale des Sciences (Turin) 1790-91: 230.

Boufford DE, Siwakoti M, Pendry CA. 2011. Rubus L. In: Watson MF, Akiyama $\mathrm{S}$, Ikeda H, et al (web-ed. 2), Flora of Nepal. The Royal Botanic Garden, Edinburgh, UK. [updated version available online at floraofnepal.org, accessed on 3 Jan. 2017].

Chowdhery HJ, Giri GS, Pal GD, et al. 1996. In: Hajra PK, Verma DM, Giri GS (eds), Materials for the Flora of Arunachal Pradesh (RanunculaceaeDipsacaceae) vol.1. Botanical Survey of India, Calcutta, India.

Chowdhery HJ, Wadhwa BM. 1984. Rosaceae. In: Chowdhery HJ, Wadhwa BM (eds), Flora of Himachal Pradesh Analysis 1: 234-261. Botanical Survey of India, Calcutta, India.

Focke WO. 1874. Batographische Abhandlungen. Abhandlungen des Naturwissenschaftlichen Vereins zu Bremen 4: 139-204.

Focke WO. 1891. Rubus L. In: Oliver D (ed), Hooker's Icones Plantarum; or figures, with brief descriptive characters and remarks of new or rare plants 20, pt. 3: t. 1951.

Focke WO. 1910. Species Ruborum, Monographiae generis Rubi Prodromus part I. Bibliotheca Botanica 17: 1-120.

Focke WO. 1911. Species Ruborum, Monographiae generis Rubi Prodromus, part II. Bibliotheca Botanica 17: 121-223.

Focke WO. 1914. Species Ruborum, Monographiae generis Rubi Prodromus, part III. Bibliotheca Botanica 19: 224-498.

Gupta C, Dash SS. 2015. Rubus sengorensis (Rosaceae): A new record to India from Arunachal Pradesh. Nelumbo 57: 50-55. doi: http://dx.doi. org/10.20324/nelumbo/v57/2015/87087.

Hooker JD. 1878. Rosaceae. In: Hooker JD (ed), The Flora of British India 2: 307-348. London, UK.

Kalkman C. 1993. Rosaceae. In: Flora Malesiana, ser. I, 11, 2: 227-351. Leiden.

Kanjilal UN, Kanjilal PC, Das A. 1922. Flora of Assam, Vol. 2. Government of Assam, India.

Kuntze CEO. 1879. Methodik der Speciesbeschreibung und Rubus. Monographie. Leipzig, Germany.

Linnaeus C. 1753. Species plantarum 1: 492. Holmiae, Sweden.

Long DG. 1987. Rubus L. In: Grierson AJC, Long DG (eds), Flora of Bhutan 1, 3: 543-562. Royal Botanic Garden, Edinburgh, UK.

Lu LD, Boufford DE. 2003. Rubus L. In: Wu ZH, Raven PH (eds), Flora of China 9: 195-286. Science Press, Beijing and Missouri Botanical Garden Press, St. Louis, USA.

McNeill J, Barrie FR, Buck WR, et al. (eds). 2012. International Code of Nomenclature for algae, fungi, and plants (Melbourne Code). Regnum Vegetabile 154. Koeltz Scientific Books, Koenigstein.

Naruhashi N. 1980. Morphology of 34 Japanese Rubus species. Acta Horticulturae 112: 177-181.

Roxburgh W. 1832. Flora Indica, Vol. 2. Srerampore, India.

Sharma BM, Kachroo P. 1981. Flora of Jammu and plants of neighbourhood, Vol. 1. Bishen Singh Mahendra Pal Singh, Dehradun, India.

Smith JE. 1819. Rubus. In: Rees A (ed), Rees's Cyclopedia, 30. Rubus no. 1-56. London, UK.

Thiers B. 2016 [continuously updated]. Index herbariorum: a global directory of public herbaria and associated staff. New York Botanical Garden's virtual herbarium (http://sweetgum.nybg.org/science/ih/, accessed on 27 Dec. 2016). 